\title{
Steady-state concentrations of mRNA encoding two inhibitors of protein kinase $C$ in ovine luteal tissue
}

\author{
J. L. Juengel ${ }^{1}$, M. H. Melner ${ }^{2}$, J. A. Clapper ${ }^{3 \dagger}$, A. M. Turzillo', \\ G. E. Moss ${ }^{3}$, T. M. Nett ${ }^{1}$ and G. D. Niswender ${ }^{1 *}$ \\ ${ }^{1}$ Animal Reproduction and Biotechnology Laboratory, Colorado State University, Fort Collins, CO 80523 , \\ USA; ${ }^{2}$ Departments of Obstetrics and Gynecology and of Cell Biology, Vanderbilt University School of \\ Medicine, Nashville, TN 37232, USA; and ${ }^{3}$ Department of Animal Science, University of Wyoming, \\ Laramie, WY 82071, USA
}

\begin{abstract}
Prostaglandin $\mathrm{F}_{2 \alpha}\left(\mathrm{PGF}_{2 \alpha}\right)$ decreases secretion of progesterone from the corpus luteum in domestic ruminants. However, it is less effective during the early part of the oestrous cycle (Louis et al., 1973) and at the time of maternal recognition of pregnancy (Silvia and Niswender, 1984; Lacroix and Kann, 1986). Decreased luteal responsiveness may be due to failure of $\mathrm{PGF}_{2 \alpha}$ to activate fully its normal second messenger system, protein kinase $\mathrm{C}$ $(\mathrm{PKC})$. Alternatively, increased resistance of the corpus luteum to $\mathrm{PGF}_{2 a}$ might be attributable to greater concentrations of recently identified biological inhibitors of PKC. These possibilities were addressed by measuring steady-state concentrations of mRNA encoding $\mathrm{PGF}_{2 a}$ receptor and two inhibitors of $\mathrm{PKC}$, protein kinase $\mathrm{C}$ inhibitor-1 (PKCI-1) and kinase $\mathrm{C}$ inhibitor protein-1 (KCIP-1, brain 14-3-3 protein), in corpora lutea collected from ewes on days 4,10 and 15 of the oestrous cycle ( $n=5$ per day) and day 15 of pregnancy $(n=7)$. There were no differences in mean concentrations of mRNA encoding $\mathrm{PGF}_{2 \alpha}$ receptor among the groups. However, concentrations of mRNA encoding both inhibitors of PKC were higher $(P<0.01)$ on day 4 of the oestrous cycle compared with the other groups. Treatment of ewes with a luteolytic dose of $\mathrm{PGF}_{2 \alpha^{\prime}}$ which activates $\mathrm{PKC}$, did not change concentrations of mRNA encoding either PKCI- 1 or KCIP-I up to $24 \mathrm{~h}$ later. Luteal expression of mRNA encoding the PKC inhibitors and $\mathrm{PGF}_{2 a}$ receptor was also examined in ewes treated with oestradiol in vivo for $16 \mathrm{~h}$ in the midluteal phase. High concentrations of oestradiol in serum $\left(20\right.$ and $\left.70 \mathrm{pg} \mathrm{ml}^{-1}\right)$ did not influence quantities of any of the mRNAs examined. Therefore, an increase in PKC inhibitors may be involved in resistance of the corpus luteum to $\mathrm{PGF}_{2 \alpha}$ during the early part of the oestrous cycle but does not appear to mediate the increased resistance of the corpus luteum to $\mathrm{PGF}_{2 a}$ during maternal recognition of pregnancy. Neither $\mathrm{PGF}_{2 \alpha}$ nor oestradiol affected steady-state concentrations of mRNAs encoding PKCI-I or KCIP-I.
\end{abstract}

\section{Introduction}

In domestic ruminants, pulsatile release of $\mathrm{PGF}_{2 u}$ from the uterus induces luteal regression (reviewed in Knickerbocker et al., 1988). $\mathrm{PGF}_{2 a}$ binds to high-affinity receptors on large luteal cells resulting in activation of $\mathrm{PKC}$ and an influx of $\mathrm{Ca}^{2+}$ into the cells (Wiltbank et al., 1991). Activation of PKC results in decreased progesterone production in both steroidogenic luteal cell types (Wiltbank et al., 1989) through multiple mechanisms, including reduced transport of cholesterol to cytochrome $\mathrm{P} 450$ side-chain cleavage $\left(\mathrm{P}^{4} 5 \mathrm{O}_{\text {scci }}\right.$ Wiltbank et al., 1993) and decreased concentrations of mRNAs encoding

*Correspondence.

${ }^{\dagger}$ Present address: Department of Animal and Range Sciences, South Dakota State University, Brookings, SD 57007-0392, USA.

Received 7 October 1997. proteins important in the steroidogenic pathway (McGuire et al., 1994; Juengel et al., 1995).

In cattle, administration of $\mathrm{PGF}_{2 \alpha}$ during the early luteal phase of the reproductive cycle does not result in luteal regression (Louis et al., 1973). In addition, corpora lutea of pregnant ewes are more resistant to $\mathrm{PGF}_{2 u}$ than those of non-pregnant ewes during maternal recognition of pregnancy (Silvia and Niswender, 1984; Lacroix and Kann, 1986). Differences in luteal responsiveness to $\mathrm{PGF}_{2 \alpha}$ could be due to fewer receptors for $\mathrm{PGF}_{2 \alpha}$ or an inability of the receptor to fully activate its second messenger systems. Recently, Wiltbank et al. (1995) demonstrated the presence of equal concentrations of $\mathrm{PGF}_{2 \alpha}$ receptors in bovine corpora lutea on days 2 and 10 of the oestrous cycle and Juengel et al. (1996) reported that mRNA encoding the $\mathrm{PGF}_{2 u}$ receptor did not change between days 3 and 15 of the oestrous cycle in the ovine corpus luteum. Therefore, numbers of $\mathrm{PGF}_{2 \alpha}$ receptors do not appear to limit 
the responsiveness of the corpus luteum to $\mathrm{PGF}_{2 u}$ during the early phase of the oestrous cycle or at the time of maternal recognition of pregnancy (Wiepz et al., 1992).

Ovine luteal cells treated with conceptal proteins show an increased resistance to pharmacological activation of PKC (Wiltbank et al., 1992), suggesting that the reduced responsiveness of corpora lutea to $\mathrm{PGF}_{2 \alpha}$ during maternal recognition of pregnancy occurs after binding of $\mathrm{PGF}_{2 u}$ to its receptor. Direct inhibition of PKC activity is an alternative explanation of the reduced responsiveness of the corpus luteum to $\mathrm{PGF}_{2 u}$. Naturally occurring proteins that inhibit PKC activity have been detected in several tissues, including the ovary (Melner, 1996). PKCI-I is a $13690 \mathrm{Da}$ zinc-binding protein that inhibits PKC even in the presence of high concentrations of calcium and phospholipid which are normal activators of the enzyme. The inhibitor is not a phosphatase nor does it prevent PKC activation by interacting with co-factors that are essential for activity (Pearson et al., 1990). PKCI-I belongs to the HIT family of proteins, designated as such due to a conserved histidine triad in the carboxy terminal domain that forms the zinc chelation site. Although the cellular functions of PKCI-I are not well understood, recent data indicate that members of the HIT family of genes display aberrant transcripts in a high percentage of digestive tract cancers (Ohta et al., 1996). However, PKCI-1 was recently identified as the single positive clone out of 300000 colonies in a yeast two-hybrid screen with the regulatory region of human PKC $\beta$ as bait (Lima et al., 1996) which supports the theory that it acts as an inhibitor of PKC. KCIP-I is an unrelated PKC inhibitor which is a member of a family of proteins (brain 14-3-3 proteins) that inhibit $\mathrm{PKC}$ and have molecular masses of $29-33 \mathrm{kDa}$. The mechanism by which KCIP-1 inhibits PKC is not known; however, it is not due to competition for co-factors required for PKC activation (Toker et al., 1992). It is possible that different concentrations of one or both of these proteins in corpora lutea could explain differences in resistance to $\mathrm{PGF}_{2 \alpha}$. Therefore, the objectives of the present study were: (1) to examine luteal concentrations of mRNAs encoding PGF $_{2 u}$ receptor, PKCI- 1 and KCIP-I under conditions in which resistance of corpora lutea to $\mathrm{PGF}_{2 \alpha}$ is known to vary; and (2) to determine the effects of $\mathrm{PGF}_{2 \alpha}$ and oestradiol, two hormones that are known to increase the luteolytic efficacy of $\mathrm{PGF}_{2 \alpha}$ (Gengenbach et al., 1977; Schramm et al., 1983), on concentrations of these mRNAs.

\section{Materials and Methods}

Western Range ewes (3-6 years old; 40-70 kg) exhibiting normal oestrous cycles ( $18 \pm 1$ days) were used in all experiments. Animals were housed in dry lot pens and fed 1.8$2.3 \mathrm{~kg}$ of alfalfa hay per day and had free access to water. Ewes were observed for oestrus twice a day in the presence of vasectomized rams. Corpora lutea were collected surgically via midventral laparotomy. All experiments were approved by the Colorado State University or the University of Wyoming Animal Care and Use Committee.

\section{Experiment 1}

Corpora lutea were collected from nonpregnant ewes on days 4,10 and 15 of the oestrous cycle ( $n=5$ per day) and from pregnant ewes on day 15 of pregnancy $(n=7)$ to test the hypothesis that resistance of the corpus luteum to $\mathrm{PGF}_{2 u}$ may be due to increased concentrations of PKCI-1 and KCIP-1. All pregnant ewes had viable embryos at the time of luteal tissue collection. Corpora lutea were decapsulated, weighed, frozen in liquid nitrogen and stored at $-70^{\circ} \mathrm{C}$ until isolation of polyadenylated ( $\operatorname{poly}(\mathrm{A})^{+}$) RNA. Blood samples were obtained from each ewe just before tissue collection for quantification of progesterone in a single radioimmunoassay (Niswender, 1973). The coefficient of variation $(\mathrm{CV})$ was $8 \%$ and the limit of sensitivity was $57 \mathrm{pg} \mathrm{ml}^{-1}$.

\section{Experiment 2}

Steady-state concentrations of mRNAs encoding the PKC inhibitors varied during the oestrous cycle. Therefore, the objective of Expt 2 was to determine whether $\mathrm{PGF}_{2 \alpha}$ regulated expression of these mRNAs. On days 11-12 of the oestrous cycle ewes were injected i.v. with $25 \mathrm{mg}$ PGF $_{2 \alpha}$ (Lutalyse, Upjohn Co., Kalamazoo, MI) followed $2 \mathrm{~h}$ later by an i.m. injection of $10 \mathrm{mg} \mathrm{PGF}_{2 \alpha}$. Corpora lutea were collected from ewes 4,12 or $24 \mathrm{~h}$ after the second injection $(n=4$ or 5 per time point). Corpora lutea were also collected from untreated ewes on day 11 or 12 of the oestrous cycle and from ewes $24 \mathrm{~h}$ after administration of saline on day 11 or 12 of the oestrous cycle ( $n=4$ per group). Corpora lutea were processed as described for Expt 1. Jugular blood samples were obtained at the time of tissue collection and progesterone concentration was determined in sera in a single assay $(\mathrm{CV}=14 \%$, limit of sensitivity $=90 \mathrm{pg} \mathrm{ml}^{-1}$ ).

\section{Experiment 3}

The objective of Expt 3 was to evaluate the influence of increased concentrations of oestradiol in serum on the expression of $m R N A s$ encoding PKC inhibitors and $\mathrm{PGF}_{2 \alpha}$ receptors. Ewes received one $(n=6)$ or five $(n=5)$ oestradiol implants s.c. on day 10 of the oestrous cycle and corpora lutea were collected $16 \mathrm{~h}$ after implantation (Turzillo et al., 1995). Corpora lutea were also collected from untreated control ewes $(n=6)$ on day 10 of the oestrous cycle. Blood samples were obtained from each ewe at $2 \mathrm{~h}$ intervals beginning $16 \mathrm{~h}$ prior to tissue collection. The oestradiol concentration in all resulting samples was determined in a single radioimmunoassay ( $\mathrm{CV}=6 \%$, sensitivity $=0.44 \mathrm{pg} \mathrm{ml}^{-1}$; Thompson et al., 1978) and the progesterone concentration in the samples obtained just prior to tissue collection was determined in a single assay $\left(\mathrm{CV}=13 \%\right.$, sensitivity $\left.=30 \mathrm{pg} \mathrm{ml}^{-1}\right)$.

\section{Quantification of $m R N A$ encoding $P G F_{2 a}$ receptor, $P K C I-1$ and KCIP-1}

Unless otherwise specified, all materials used in these experiment were purchased from Sigma Chemical Co. (St Louis, MO) or Fisher Scientific (Denver, CO). Concentrations of $\mathrm{PGF}_{2 a}$ receptor mRNA were quantitated as described by Juengel et al. (1996) using a cDNA encoding a portion of the ovine $\mathrm{PGF}_{2 a}$ receptor. Slot blot analyses were performed using $\left[{ }^{32} \mathrm{P}\right]-$ deoxycytidine-5' -triphosphate (dCTP)-labelled cDNA (specific 
activity $0.3-1.0 \times 10^{9}$ disintegrations per minute (d.p.m.) $\mu \mathrm{g}^{-1}$ DNA; Feinberg and Volgelstein, 1983). Intra-assay CV averaged $12 \%$ and interassay $\mathrm{CV}$ was $14 \%$. All standard curves were linear $(r=0.99)$. The sensitivity of detection of $\mathrm{PGF}_{2 u}$

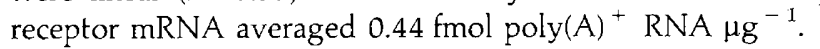

A 360 base pair (bp) cDNA encoding bovine PKCI-I (Melner et al., 1993) was used to quantitate mRNA encoding PKCI-1 in ovine luteal tissue. Specificity of this CDNA was determined with northern analysis (Sambrook et al., 1989). Poly $(A)^{+}$RNA was isolated from various ovine tissues by binding to oligo(deoxythymidine)-cellulose (oligo(dT)cellulose, Collaborative Biomedical Products, Bedford, MA) (Badley et al., 1988; Guy et al., 1995). The concentration of RNA was quantified by absorption at $260 \mathrm{~nm}$. Samples of poly $(\mathrm{A})^{+}$RNA $(5 \mu \mathrm{g})$ were separated on a $1.5 \%$ agaroseformaldehyde-3[N-morpholino]propanesulfonic acid gel, transferred to a nylon filter (Hybond, Amersham Corp., Arlington Heights, IL) by capillary action, and cross-linked to filters by ultraviolet light (Stratalinker, La Jolla, CA). The filter was prehybridized overnight at $42^{\circ} \mathrm{C}$ in hybridization buffer (fivestrength salt sodium citrate (SSC) $(750 \mathrm{mmol}$ sodium chloride $\mathrm{I}^{-1}$ and $75 \mathrm{mmol}$ sodium citrate $\left.\mathrm{l}^{-1}\right), 0.1 \%(\mathrm{w} / \mathrm{v})$ Ficoll 400 , $0.1 \%(\mathrm{w} / \mathrm{v})$ polyvinylpyrrolidone, $0.1 \%(\mathrm{w} / \mathrm{v})$ BSA (US Biochemicals, Cleveland, OH), 0.1\% (w/v) SDS, $50 \%(\mathrm{v} / \mathrm{v})$ deionized formamide (Gibco BRL, Gaithersburg, MD), $50 \mathrm{mmol} \mathrm{NaPO}_{4} \mathrm{l}^{-1}$, and $100 \mu \mathrm{g} \mathrm{ml}^{-1}$ heat-denatured salmon sperm DNA). The filter was then incubated in hybridization buffer containing $2 \times 10^{6}$ counts per minute (c.p.m.) $\mathrm{ml}^{-1}$ PKCI-I $\left[{ }^{32} \mathrm{P}\right] \mathrm{CDNA}$ (generated using the random primer method; specific activity $0.3-1.0 \times 10^{9}$ d.p.m. $\mu g^{-1}$ DNA) at $42^{\circ} \mathrm{C}$ for $24 \mathrm{~h}$. After hybridization, the filter was washed four times in double-strength SSC and 0.1\% SDS at room temperature for $10 \mathrm{~min}$ and was then washed twice in 0.1 strength SSC and $0.1 \%$ SDS at $65^{\circ} \mathrm{C}$ for $30 \mathrm{~min}$. Filters were then exposed to Kodak X-AR film (Eastman Kodak, Rochester, NY) with intensifying screens for $0.5-3$ days at $-70^{\circ} \mathrm{C}$. The concentration of mRNA encoding PKCI- 1 in individual luteal samples was determined by slot blot analysis. Poly $(A)^{+}$RNA was isolated from corpora lutea as described for the northern blot analysis. Duplicate aliquots of $300 \mathrm{ng}$ poly $(\mathrm{A})^{+}$RNA from individual luteal samples were applied to nylon filters with a slot blot apparatus. Various quantities $(5,10,30,50,100,300$ and $500 \mathrm{ng}$ ) of appropriate sense mRNA generated with SP6 polymerase and positive control RNA (100,300 and $500 \mathrm{ng}$ of pooled luteal poly $(\mathrm{A})^{+}$RNA) were also included on each filter. Conditions for prehybridization, hybridization and washing of filters were as described for the northern analysis. Comparison of hybridization of PKCI-I [ $\left.{ }^{32} \mathrm{P}\right] \mathrm{CDNA}$ to samples and standard, as measured by densitometric scanning (Hoefer Scientific Instruments, San Francisco, CA) of autoradiographs, was used to calculate the concentration of mRNA encoding PKCI-1 in individual samples. All standard curves for synthesized PKCI-1 mRNA were linear with high correlation between the quantity of standard added and resulting densitometric reading $(r=0.99)$. Quantities of PKCI-I mRNA were linear $(r=0.99)$ in 100-500 ng pooled luteal poly $(\mathrm{A})^{+}$RNA. Intra- and interassay CVs were less than $13 \%$ and the limit of detection averaged $0.15 \mathrm{fmol}$ poly $(\mathrm{A})^{+} \mathrm{RNA} \mu \mathrm{g}^{-1}$.

CDNA was generated from luteal poly $(A)^{+}$RNA with a primer corresponding to bases $653-668$ of the bovine KCIP-1
cDNA (Ichimura et al., 1988) and reverse transcriptase to generate a cDNA encoding ovine KCIP-1. The ovine cDNA encoding KCIP-I was amplified by PCR (40 cycles of denaturing at $94^{\circ} \mathrm{C}$ for $1 \mathrm{~min}$, annealing at $60^{\circ} \mathrm{C}$ for $1 \mathrm{~min}$, extension at $72^{\circ} \mathrm{C}$ for 2 min; GeneAMP, Perkin Elmer Cetus, Norwalk, CT) with primers specific for bases $303-322$ and $653-668$ of the bovine KCIP-I cDNA (Ichimura et al., 1988). The resulting $355 \mathrm{bp}$ fragment was ligated into pCRII (Invitrogen, San Diego, CA) and the sequence determined by the dideoxy procedure (Sequenase Version 2.0, US Biochemicals, Cleveland, $\mathrm{OH}$; Chen and Seeburg, 1985). The insert was released from the plasmid with ECo RI and gel purified. The purified insert was used for northern and slot blot analyses after incorporation of $\left.{ }^{32} \mathrm{P}\right] \mathrm{dCTP} \quad\left(111 \mathrm{TBq} \mathrm{mmol}^{-1}\right.$; Amersham, Arlington Heights, IL) by the random primer method (specific activity $0.3-1.0 \times 10^{9}$ d.p.m. $\mu \mathrm{g}^{-1}$ DNA; Feinberg and Volgelstein, 1983).

Tissue distribution and size of ovine KCIP-I mRNA were determined by northern analysis as described for PKCl-1. Quantities of mRNA encoding KCIP-1 in individual luteal samples were determined by slot blot analysis. Sense RNAs for KCIP-I were synthesized by transcribing the Bam HI-linearized plasmid containing KCIP-I with T7 polymerase to generate a standard curve. All standard curves were linear $(r=0.99)$. Quantities of KCIP-1 mRNA were linear $(r=0.98)$ in 100$500 \mathrm{ng}$ of pooled luteal poly $(\mathrm{A})^{+}$RNA. Intra-assay $\mathrm{CV}$ averaged $16 \%$ and interassay $\mathrm{CV}$ was $25 \%$. The limit of detection of KCIP-I mRNA, based on the lowest detectable point in the standard curve, averaged $0.15 \mathrm{fmol}$ poly $(A)^{+}$ RNA $\mu g^{-1}$.

After hybridization to specific cDNA, all filters were hybridized with $\left[{ }^{32} \mathrm{P}\right]$ deoxythymidine $(\mathrm{d}(\mathrm{T}))$ as described by Juengel et al. (1994) to determine whether equal quantities of poly $(A)^{+}$ RNA were loaded on slots within each filter. Correlation between different concentrations of RNA applied to the filters and densitometric signals was high $(r=0.97 \pm 0.01)$. CV between densitometric reading of samples averaged $18 \%$ for all filters. Therefore, measurements of mRNA encoding $\mathrm{PGF}_{2 u}$ receptor, PKCI-1 and KCIP-I were not corrected for differences in RNA loading.

\section{Statistical analysis}

In ewes with multiple ovulations, the average mass of corpora lutea was used for statistical analysis. All analyses were performed using the general linear models procedures of SAS (1989). In Expt 2, there were no differences between salineinjected and non-injected controls in any parameter examined. Therefore, data from these two groups were combined prior to final statistical analysis and are referred to as controls. In Expt 3 concentrations of oestradiol in sera (average of samples collected during the last $14 \mathrm{~h}$ before tissue collection) were square root transformed prior to final analysis due to heterogeneity of variance. However, means \pm SEM of raw data are presented. In Expts 2 and 3, values for the mRNAs (fmol

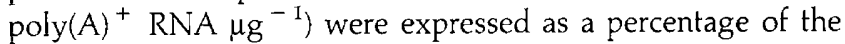
mean control value. Data from all experiments were tested with analysis of variance procedures and when treatment effects 


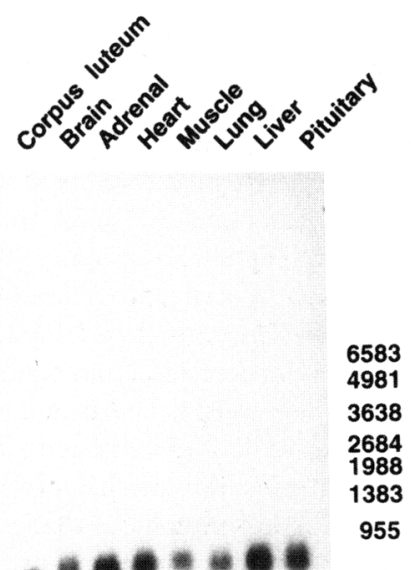

Fig. 1. Autoradiograph (overnight exposure) of northern blot analysis of ovine poly $(\mathrm{A})^{+}$RNA samples $(5 \mu \mathrm{g})$ hybridized with bovine protein kinase $C$ inhibitor- 1 CDNA. Tissue source is indicated along the top of the figure. Migration of RNA standards is shown on the right in bases.

were significant $(P<0.05)$ differences between least squares means were evaluated by least significant differences.

\section{Results}

The cDNA encoding bovine PKCI-1 hybridized to a single transcript of approximately 780 bases in all tissues examined (Fig. 1). The apparent smaller size of this transcript in luteal tissue was due to aberrant migration of RNA at the edge of the gel. The nucleotide sequence obtained from the ovine KCIP-1 cDNA was $95 \%$ identical to the corresponding region of rat brain 14-3-3 $\theta$ sequence (Watanabe et al., 1994). A primary transcript of approximately 2280 bases was observed in all tissues examined following hybridization to the ovine KCIP-1 CDNA (Fig. 2). A second minor transcript of approximately 4300 bases was observed in brain and adrenal tissues.

In Expt 1, luteal mass and serum progesterone concentrations increased $(P<0.05)$ between days 4 and 10 of the oestrous cycle, as also reported by Juengel et al. (1995). Luteal mass was similar between days 10 and 15 of the oestrous cycle and day 15 of pregnancy. However, serum progesterone concentrations were higher $(P<0.05)$ on day 15 of pregnancy compared with days 10 or 15 of the oestrous cycle. Steadystate luteal concentrations of mRNA encoding both PKCI-1 and KCIP-I were greater $(P<0.01)$ on day 4 of the oestrous cycle than on days 10 or 15 (Fig. 3). There was no difference in the concentration of mRNA encoding the $\mathrm{PGF}_{2 \alpha}$ receptor on these days (Fig. 3). Luteal concentrations of mRNAs encoding the PKC inhibitors and the $\mathrm{PGF}_{2 u}$ receptor on day 15 of the oestrous cycle and day 15 of pregnancy were not significantly different (Fig. 3). In Expt 2, injection of a luteolytic dose of
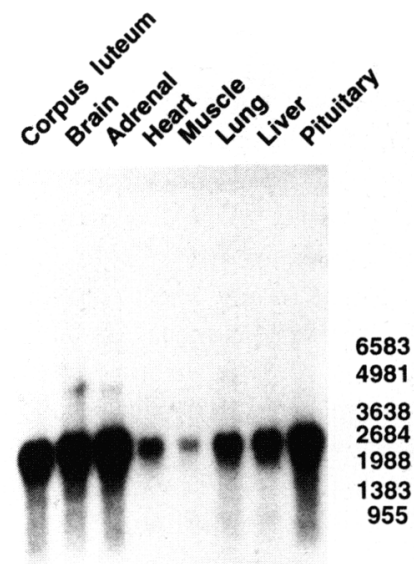

Fig. 2. Autoradiograph (overnight exposure) of northern blot analysis of ovine poly $(\mathrm{A})^{+}$RNA samples $(5 \mu \mathrm{g})$ hybridized with ovine protein kinase $C$ inhibitor-I cDNA. Tissue source is indicated along the top of the figure. Migration of RNA standards is shown on the right in bases.

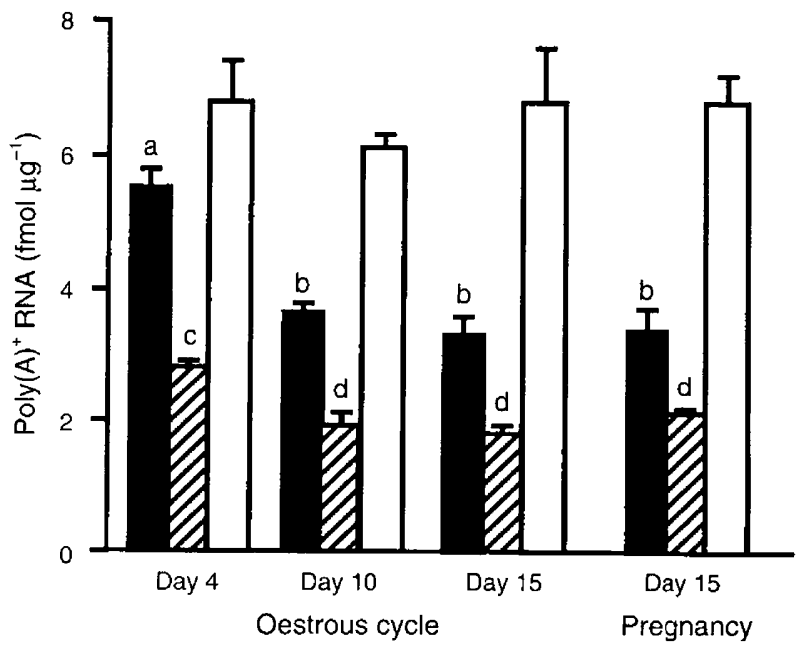

Fig. 3. Ovine luteal concentrations of ( $\boldsymbol{\square}$ ) protein kinase $C$ inhibitor-1, $(\because)$ kinase $C$ inhibitor protein- $I$ and $(\square)$ prostaglandin $F_{2 u}$ receptor mRNA on days 4,10 and 15 of the oestrous cycle and day 15 of pregnancy. For each class of mRNA, differences between time periods are indicated by different letters $(P<0.01)$.

$\mathrm{PGF}_{2 u}$ resulted in a decrease in both serum progesterone concentration and luteal mass (Juengel et al., 1996) but did not affect the concentrations of mRNA encoding PKCI-1 or KCIP-1 (Fig. 4). In Expt 3, ewes administered with one or five oestradiol implants had mean serum oestradiol concentrations that were 15.8- and 54.1-fold higher, respectively, than control ewes (Table I). However, exposure to oestradiol for $16 \mathrm{~h}$ did not affect serum progesterone concentrations, luteal mass or luteal concentrations of mRNA encoding PKCI-1, KCIP-I or $\mathrm{PGF}_{2 \alpha}$ receptor (Table I). 


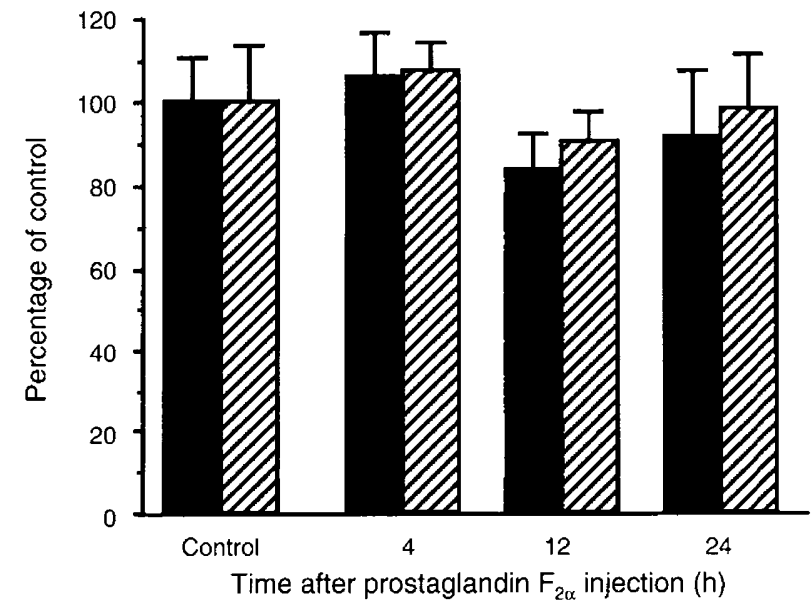

Fig. 4. Concentrations of $(\square)$ protein kinase $C$ inhibitor- $I$ and $(\nabla A)$ kinase $\mathrm{C}$ inhibitor protein- $\mathrm{I}$ mRNA in corpora lutea collected from ewes 4,12 or $24 \mathrm{~h}$ after injection with prostaglandin $\mathrm{F}_{2 u}$. There were no differences among groups.

\section{Discussion}

The cDNA encoding bovine PKCI- 1 hybridized to a transcript of approximately 780 bases in all ovine tissues examined. The widespread distribution of this mRNA was similar to previous reports and was not unexpected due to the presence of PKC in a variety of tissues (Melner, 1996).

The partial cDNA encoding ovine KCIP-1 was $95 \%$ identical to the rat $\theta$ KCIP-1 isoform reported by Watanabe et al. (1994). The sequence also shared significant similarity $(57-72 \%)$ to other isoforms of KCIP-1 (Watanabe et al., 1991, 1993, 1994; Roseboom et al., 1994). However, this cDNA sequence detected a single major transcript of approximately 2280 bases when used in northern blot analysis. Therefore, hybridization conditions were sufficiently stringent to prevent crosshybridization of the CDNA to related isoforms of KCIP-1. This mRNA is similar in size to a major transcript for $\theta$ subtype of KCIP- 1 observed in rat brain RNA although other transcripts were also observed in the rat. The differences in size of mRNA in the rat were most likely due to differences in polyadenylation sites (Watanabe et al., 1994). The $\theta$ subtype of KCIP-I protein is a potent PKC inhibitor (Robinson et al., 1994) with an $\mathrm{IC}_{50}$ value (the concentration that inhibits the response by $50 \%$ ) of less than $50 \%$ of that observed for sheep brain isoform mixture.

Concentrations of mRNA encoding both inhibitors of PKC were higher on day 4 of the oestrous cycle compared with days 10 or 15. In rat ovary, expression of PKCl-1 mRNA decreases when actively growing follicles differentiate into corpora lutea (Melner, 1996). This decrease may continue until a fully differentiated corpus luteum is present. In contrast to the increased concentrations of mRNAs encoding PKC inhibitors during the early luteal phase, there were no differences between day 15 of the oestrous cycle and day 15 of pregnancy. Therefore, an increase in mRNAs encoding PKC inhibitors, and the associated increase in the corresponding proteins, may be involved in resistance of the corpus luteum to $\mathrm{PGF}_{2 \alpha}$ during the early part of the oestrous cycle, but does not appear to mediate the increased resistance of the corpus luteum to $\mathrm{PGF}_{2 \alpha}$ during maternal recognition of pregnancy. Furthermore, the low expression of mRNA encoding PKC inhibitors during maternal recognition of pregnancy may explain why corpora lutea present at this stage respond to high doses of $\mathrm{PGF}_{2 u}$ with decreased secretion of progesterone, but those present in the early luteal phase do not.

There were no differences in the steady-state concentrations of mRNA encoding PGF $_{2,1}$ receptor on days 4,10 and 15 of the oestrous cycle and day 15 of pregnancy. These data are similar to the observations of Juengel et al. (1996). Wiepz et al. (1992) also reported that there were no differences in the number of $\mathrm{PGF}_{2 \mu}$ receptors on days 13 and 15 of pregnancy or on day 13 of pregnancy compared with day 13 of the oestrous cycle. However, this study did detect more $\mathrm{PGF}_{2 u}$ receptors on day 15 of pregnancy compared with day 15 of the oestrous cycle. In addition, Rueda et al. (1995) reported that concentrations of mRNA encoding $\mathrm{PGF}_{2 u}$ receptor were higher on day 16 of pregnancy when compared with day 16 of the oestrous cycle. The discrepancies between these studies may be due to the negative effects of $\mathrm{PGF}_{2 u}$ on its receptor mRNA (Graves et al., 1995; Juengel et al., 1996) and the timing of luteolysis in ewes which is initiated around day 15 of the oestrous cycle.

Multiple injections of $\mathrm{PGF}_{2 u}$ are more effective in inducing luteolysis than a single injection of $\mathrm{PGF}_{2 \mu}$ (Schramm et al., 1983). The effect of treatment with $\mathrm{PGF}_{2 u}$ on the concentrations of mRNA encoding PKC inhibitors was examined in the present study. Injection of $\mathrm{PGF}_{2 u}$ did not affect the concentrations of mRNA encoding either PKC-1 or KCIP-1. Juengel et al. (1996) reported that concentrations of mRNA encoding $\mathrm{PGF}_{2 \alpha}$ receptor decreased to $20 \%$ of the concentration in controls $12 \mathrm{~h}$ after $\mathrm{PGF}_{2 u}$ injection. Therefore, neither a decrease in PKC inhibitors nor an increase in $\mathrm{PGF}_{2 \alpha}$ receptor mRNA appears to be the cause of the increased sensitivity of the corpus luteum to $\mathrm{PGF}_{a}$ after treatment with $\mathrm{PGF}_{2 \omega}$.

Treatment with oestradiol increases the luteolytic efficacy of $\mathrm{PGF}_{2 \alpha}$ (Gengenbach et al., 1977) and also increases the number of $\mathrm{PGF}_{2 a}$ receptors in luteal tissue (Bussmann, 1989). In hysterectomized ewes, treatment with a combination of oestradiol and $\mathrm{PGF}_{2 \alpha}$ reduces the concentration of $\mathrm{PGF}_{2 u}$ needed to induce luteolysis (Gengenbach et al., 1977). Therefore, oestradiol appears to increase the responsiveness of the corpus luteum to $\mathrm{PGF}_{2 \alpha}$ directly. The effect of treatment with oestradiol on concentrations of mRNA encoding PKCI-1, KCIP-I and $\mathrm{PGF}_{2 \mu}$ receptor was examined in the present study. Treatment of ewes with high doses of oestradiol for $16 \mathrm{~h}$ did not change luteal mass, serum progesterone concentrations or concentrations of mRNAs encoding PGF $_{2 \alpha}$ receptor, PKCl-1 or KCIP-1. In previous studies, injection of oestradiol was found to decrease serum progesterone concentrations and luteal mass (Stormshak et al., 1969; Hawk and Bolt, 1970; Hixon et al., 1975). The absence of a similar response to oestradiol in corpora lutea in the present experiment may be due to the shorter exposure time of the ewes to oestradiol. Therefore, assuming that concentrations of mRNAs and their associated proteins are tightly correlated, as has been shown for the $\mathrm{PGF}_{2 \alpha}$ receptor (Sakamoto et al., 1994), the increased efficacy of $P \mathrm{FF}_{2 u}$ after treatment with oestradiol does not appear to be mediated through changes in $\mathrm{PGF}_{2 u}$ receptor, PKCI-1 or KCIP-1 concentrations. Previous studies have shown that large luteal cells in ewes contain receptors for both oestradiol (Glass et al., 1984) 
Table 1. Serum progesterone and serum oestradiol concentrations, luteal mass and luteal concentrations of mRNAs encoding protein kinase $C$ inhibitor- 1 , kinase $C$ inhibitor protein- 1 and prostaglandin $F_{2 u}$ receptor during the midluteal phase in ewes $16 \mathrm{~h}$ after treatment with oestradiol implants

\begin{tabular}{lccc}
\hline & \multicolumn{3}{c}{ Number of oestradiol implants } \\
\cline { 2 - 4 } & 0 & 1 & 5 \\
\hline Progesterone $\left(\mathrm{ng} \mathrm{ml}^{-1}\right.$ ) & & & $1.8 \pm 0.4$ \\
Oestradiol (pg ml ${ }^{-1}$ ) & $1.3 \pm 0.3$ & $1.6 \pm 0.2$ & $70.3 \pm 7.4^{\mathrm{c}}$ \\
Luteal mass (mg) & $597.0 \pm 59.0$ & $554.0 \pm 20.0$ & $543.0 \pm 54.0$ \\
Protein kinase C inhibitor-1 mRNA* & $100.0 \pm 16.0$ & $95.0 \pm 9.0$ & $111.0 \pm 9.0$ \\
Kinase C inhibitor protein-1 mRNA* & $100.0 \pm 13.0$ & $88.0 \pm 8.0$ & $93.0 \pm 9.0$ \\
Prostaglandin $\mathrm{F}_{2, \alpha}$ receptor mRNA* & $100.0 \pm 17.0$ & $92.0 \pm 13.0$ & $103.0 \pm 20.0$ \\
\hline
\end{tabular}

Values are means \pm SEM.

${ }^{a b c}$ Within each parameter, values with different superscripts are significantly different $(P<0.001)$.

*Percentage of corresponding values in ewes not treated with oestradiol implants.

and $\mathrm{PGF}_{2 u}$ (Fitz et al., 1982) and luteal $\mathrm{PGF}_{2 u}$ receptors in rats are upregulated by oestradiol (Bussmann, 1989). Therefore, the absence of an effect of oestradiol on mRNA encoding PGF 20 receptor is surprising. Differences between the present results and those in rats may be attributed to differences between species, differences in oestradiol concentration, or different endpoint measurements (mRNA versus binding of $\mathrm{PGF}_{2 \alpha}$ ).

In conclusion, the increased resistance of the corpus luteum to $\mathrm{PGF}_{2 u}$ during the early part of the oestrous cycle may be due to increased concentrations of mRNA encoding PKCI- 1 and $\mathrm{KCIP}$, and the associated increase in the corresponding proteins. However, increased concentrations of mRNAs encoding PKCI-1 or KCIP do not appear to mediate increased resistance of the corpus luteum during maternal recognition of pregnancy. In addition, neither $\mathrm{PGF}_{2 \alpha}$ nor oestradiol, hormones that are known to increase the luteolytic efficacy of $\mathrm{PGF}_{2 \alpha^{\prime}}$ affected concentrations of mRNA encoding PKCI- 1 or KCIP-1. In addition, oestradiol did not increase luteal expression of $\mathrm{PGF}_{2 \alpha}$ receptor $\mathrm{mRNA}$.

This research was supported by NIH grant HD 11590 and the Colorado and Wyoming Agricultural Experiment Stations. The authors appreciate the invaluable technical assistance of M. Gallegos, B. Meberg, C. Moeller, K. Sutherland and E. Van Kirk. They would also like to thank C. Discafani, D. Haworth, H. Sawyer and W. Mellion for their help in tissue collection.

\section{References}

Badley JE, Bishop GA, St John T and Frelinger JA (1988) A simple, rapid method for the purification of poly $(A)+$ RNA Biotechniques $6114-116$

Bussmann LE (1989) Prostaglandin F-2 $\alpha$ receptors in corpora lutea of pregnant rats and relationship with induction of $20 \alpha$-hydroxysteroid dehydrogenase Journal of Reproduction and Fertility 85 331-341

Chen EY and Seeburg PH (1985) Laboratory methods. Supercoil sequencing: a fast and simple method for sequencing plasmid DNA DNA 4 165-170

Feinberg AP and Volgelstein B (1983) A technique for radiolabelling DNA restriction endonuclease fragments to high specific activity Analytical Biochemistry 132 6-13

Fitz TA, Mayan MH, Sawyer HR and Niswender GD (1982) Characterization of two steroidogenic cell types in the ovine corpus luteum Biology of Reproducfion 27 703-711
Gengenbach DR, Hixon JE and Hansel W (1977) A luteolytic interaction between estradiol and prostaglandin $F_{2 u}$ in hysterectomized ewes Biology of Reproduction 16 571-579

Glass JD, Fitz TA and Niswender GD (1984) Cytosolic receptor for estradiol in the corpus luteum of the ewe: variation throughout the estrous cycle and distribution between large and small steroidogenic cell types Biology of Reproduction 31 967-974

Graves PE, Pierce KL, Bailey TJ, Rueda BR, Gil DW, Woodward DF, Yool AJ, Hoyer PB and Regan JW (1995) Cloning of a receptor for prostaglandin $\mathrm{F}_{2 u}$ from the ovine corpus luteum Endocrinology 136 3430-3436

Guy MK, Juengel JL, Tandeski TR and Niswender GD (1995) Steady-state concentrations of mRNA encoding the receptor for luteinizing hormone during the estrous cycle and following prostaglandin $\mathrm{F}_{2 \alpha}$ treatment of ewes Endocrine 3 585-589

Hawk HW and Bolt DJ (1970) Luteolytic effect of estradiol-17 $\beta$ when administered after midcycle in the ewe Biology of Reproduction 2 275-278

Hixon JE, Gengenbach DR and Hansel W (1975) Failure of prostaglandin $F_{24}$ to cause luteal regression in ewes after destruction of ovarian follicles by X-irradiation Biology of Reproduction 13 126-135

Ichimura T, Isobe T, Okuyama T, Takahashi N, Ariaki K, Kuwano R and Takahashi $Y$ (1988) Molecular cloning of cDNA coding for brain-specific 14-3-3 protein, a protein kinase-dependent activator of tyrosine and tryptophan hydroxylases Proceedings of the National Academy of Sciences USA 85 70847088

Juengel JL, Guy MK, Tandeski TR, McGuire WJ and Niswender GD (1994) Steady-state concentrations of messenger ribonucleic acid encoding cytochrome $\mathrm{P} 450$ side-chain cleavage and $3 \beta$-hydroxysteroid dehydrogenase/ $\Delta^{5}, \Delta^{4}$ isomerase in ovine corpora lutea during the estrous cycle Biology of Reproduction 51 380-384

Juengel JL, Meberg BM, Turzillo AM, Nett TM and Niswender GD (1995) Hormonal regulation of mRNA encoding steroidogenic acute regulatory protein in ovine corpora lutea Endocrinology $1365423-5429$

Juengel JL, Wiltbank MC, Meberg BM and Niswender GD (1996) Regulation of steady-state concentrations of messenger ribonucleic acid encoding prostaglandin $\mathrm{F}_{2 u}$ receptor in ovine corpus luteum Biology of Reproduction $\mathbf{5 4}$ 1096-1102

Knickerbocker JJ, Wiltbank MC and Niswender GD (1988) Mechanisms of luteolysis in domestic livestock Domestic Animal Endocrinology 5 91-107

Lacroix MC and Kann G (1986) Aspects of the antiluteolytic activity of the conceptus during early pregnancy in ewes journal of Animal Science 63 1449-1458

Lima CD, Klein MG, Weinstein IB and Hendrickson WA (1996) Threedimensional structure of human protein kinase $\mathrm{C}$ interacting protein $\mathrm{I}$, a member of the HIT family of proteins Proceedings of the National Academy of Sciences USA 93 5357-5362

Louis TM, Hafs HD and Seguin BF (1973) Progesterone, LH estrus and ovulation after prostaglandin $\mathrm{F}_{2,4}$ in heifers Proceedings of the Society for Experimental Biology and Medicine 143 152-155 
McGuire WJ, Juengel JL and Niswender GD (1994) Protein kinase C second messenger system mediates the antisteroidogenic effects of prostaglandin $\mathrm{F}_{2 n}$ in the ovine corpus luteum in vivo. Biology of Reproduction 51 800-806

Melner MH (1996) Physiological inhibitors of protein kinase C Biochemical Pharmacology 51 869-877

Melner MH, Searles RP, Spindel ER, Kaynard AH and Nagalla SR (1993) Cloning and expression of an inhibitor of protein kinase $C$ in humans Endocrinology Supplement 132538

Niswender GD (1973) Influence of site of conjugation on the specificity of antibodies to progesterone Steroids 22 413-424

Ohta M, Inoue H, Cotticelli MG et al. (1996) The FHIT gene, spanning the chromosome 3p14.2 fragile site and renal carcinoma-associated $t(3 ; 8)$ breakpoint, is abnormal in digestive tract cancers Cell $\mathbf{8 4} 587-597$

Pearson JD, DeWald DB, Mathews WR et al. (1990) Amino acid sequence and characterization of a protein inhibitor of protein kinase C Joumal of Biological Chemistry $2654583-4591$

Robinson K, Jones D, Patel Y, Martin H, Madrazo J, Martin S, Howell S, Elmore M, Finnen MJ and Aitken A (1994) Mechanism of inhibition of protein kinase $C$ by 14-3-3 isoforms: 14-3-3 isoforms do not have phospholipase $A_{2}$ activity Biochemistry Journal 299 853-861

Roseboom PH, Weller JL, Babila T, Aitken A, Sellers LA, Mffett JR, Namboodiri MAA and Klein DC (1994) Cloning and characterization of the $\varepsilon$ and $\zeta$ isoforms of the 14-3-3-proteins DNA and Cell Biology 13 629-640

Rueda BR, Botros IW, Pierce KL, Regan JW and Hoyer PB (1995) Comparison of mRNA levels for the $\mathrm{PGF}_{2 u}$ receptor (FP) during luteolysis and early pregnancy in the ovine corpus luteum Endocrine 3 781-787

Sakamoto K, Miwa K, Ezashi T, Okuda-Ashitaka E, Okauda K, Houtani T, Sugimoto T, Ito $S$ and Haysishi O (1994) Expression of mRNA encoding the prostaglandin $\mathrm{F}_{2 a}$ receptor in bovine corpora lutea throughout the oestrous cycle and pregnancy Journal of Reproduction and Fertility 103 99-105

Sambrook J, Fritsch EF and Maniatis T (1989) Molecular Cloning: A Laboratory Manual, 2nd Edn Coldspring Harbor Laboratory Press, Coldspring Harbor, NY

SAS (1989) SAS User's Guide, Statistics Statistical Analysis System Institute Inc., Cary, NC

Schramm W, Bovaird L, Glew, ME, Schramm G and McCracken JA (1983) Corpus luteum regression induced by ultra-low pulses of prostaglandin $\mathrm{F}_{211}$ Prostaglandins $26 \quad 347-364$

Silvia WJ and Niswender GD (1984) Maintenance of the corpus luteum of early pregnancy in the ewe. III. Differences between pregnant and nonpregnant ewes in luteal responsiveness to prostaglandin $\mathrm{F}_{2 .}$ Journal of Animal Science 59 $746-753$

Stormshak F, Kelley HE and Hawk HW (1969) Suppression of ovine luteal function by 17ß-estradiol Journal of Animal Science 29 476-478
Thompson DL, Jr, Pickett BW and Nett TM (1978) Effect of season and artificial photoperiod on levels of estradiol-17 $\beta$ and estrone in blood serum of stallions Journal of Animal Science 47 184-187

Toker A, Ellis CA, Sellers LA and Aitken A (1990) Protein kinase C inhibitor proteins. Purification from sheep brain and sequence similarity to lipocortins and 14-3-3 protein European Journal of Biochemistry 191 421-429

Turzillo AM, DiGregorio GB and Nett TM (1995) Messenger ribonucleic acid for gonadotropin-releasing hormone receptor and numbers of gonadotropinreleasing hormone receptors in ovariectomized ewes after hypothalamicpituitary disconnection and treatment with estradiol Journal of Animal Science 73 1784-1788

Watanabe $M$, Isobe $T$, Okuyama T, Ichimura T, Kuwano R, Takahashi $Y$ and Kondo $\mathrm{H}$ (1991) Molecular cloning of cDNA to rat 14-3-3 $\eta$ chain polypeptide and the neuronal expression of the mRNA in the central nervous system Molecular Brain Research 10 151-158

Watanabe M, Isobe T, Ichimura T, Kuwano R, Takahashi Y and Kondo H (1993) Molecular cloning of rat $\mathrm{cDNAs}$ for $\beta$ and $\gamma$ subtypes of 14-3-3 protein and developmental changes in expression of their mRNAs in the nervous system Molecular Brain Research 17 135-146

Watanabe $M$, Isobe T, Ichimura T, Kuwano R, Takahashi $Y$, Kondo $\mathrm{H}$ and Inoue $\mathrm{Y}$ (1994) Molecular cloning of rat cDNAs for the $\zeta$ and $\theta$ subtypes of 14-3-3 protein and differential distributions of their mRNAs in the brain Molecular Brain Research 25 113-121

Wiepz GJ, Wiltbank MC, Niswender GD and Saywer HR (1992) Receptors for prostaglandin $(\mathrm{PG}) \mathrm{F}_{2 u}$ and $\mathrm{PGE}_{2}$ in ovine corpora lutea during maternal recognition of pregnancy Biology of Reproduction 47 984-99I

Wiltbank MC, Knickerbocker JJ and Niswender GD (1989) Regulation of the corpus luteum by protein kinase C. I. Phosphorylation activity and steroidogenic action in large and small ovine luteal cells Biology of Reproduction $\mathbf{4 0}$ $1194-1200$

Wiltbank MC, Diskin MG and Niswender GD (199I) Differential actions of second messenger systems in the corpus luteum Journal of Reproduction and Fertility Supplement 43 65-75

Wiltbank MC, Wiepz GJ, Knickerbocker JJ, Belfiore C and Niswender GD (1992) Proteins secreted from the early ovine conceptus block the action of prostaglandin $F_{24}$ on large luteal cells Biology of Reproduction $46475-$ 482

Wiltbank MC, Belfiore CJ and Niswender GD (1993) Steroidogenic enzyme activity after acute activation of protein kinase (PK) A and PKC in ovine small and large luteal cells Molecular and Cellular Endocrinology 97 1-7

Wiltbank MC, Shiao TF, Bergfelt DR and Ginther OJ (1995) Prostaglandin $\mathrm{F}_{2 u}$ receptors in the early bovine corpus luteum Biology of Reproduction $\mathbf{5 2}$ $74-78$ 